\title{
Livsmedelsindustrin och folkhälsan
}

\author{
Stephan Rössner
}

Överviktsenheten Huddinge universitetssjukhus, SE-I4I 86 Stockholm, Sweden

Professor Marion Nestle, känd för sin nyligen utkomna kontroversiella bok "Food Politics How the Food Industry Influences Nutrition and Health" (University of California Press, Los Angeles, Pris \$ 29,95) har nyligen på inbjudan av Måltidsakademien, föreläst i Stockholm. Stephan Rössner var en av arrangörerna. Han sammanfattar här boken och seminariet.

Den dramatiska ökningen av fetma ses allra tydligast i USA. Varje år kan man uppmäta en viktökning, till och med hos tonåringarna. Diabetes är en av fetmans vanligaste följeslagare. Den form som tidigare kallades "åldersdiabetes" börjar nu dyka upp även hos tonåringar.

Det är ingen brist på våra möjligheter att producera mat förhållandevis billigt - bara att distribuera den rättvist. I USA kan man för varenda amerikan, från spädbarn till åldringar, producera cirka 3.800 kalorier per dag, vilket är dubbelt så mycket som man i genomsnitt behöver. Näringsforskaren Marion Nestle i New York har frågat sig varför det ligger $\mathrm{i}$ all företagsamhets natur att expandera, eftersom detta i livsmedelsindustrins fall ju endast skulle leda till ännu mera överproduktion av mat.

\section{Livsmedelsindustrins alternativ}

Om man nu redan i dagsläget producerar mycket mera föda än vad som behövs för hälsa och överlevnad har industrin två alternativa strategier för att sälja sina produkter. Antingen kan man sälja sin egen produkt på någon annans bekostnad genom aktiv marknadsföring. Eller också kan man försöka få alla att öka sitt födointag. I praktiken går livsmedelsindustrin naturligtvis båda vägarna. De stora livsmedelsjättarna spenderar årligen astronomiska summor på marknadsföring, och varje gång någon statlig myndighet gör en kraftsamling för att försöka göra en hälsokampanj är budgeten för en sådan insats bara en bråkdel av vad livsmedelsjättarna kan spendera. Och självfallet påverkas vi av budskapet. Via TV, radio och alla tryckta media exponeras vi oavbrutet för avancerade kampanjer. Anmärkningsvärt är, att livsmedelsindustrin under senare år, framför allt i USA, har specialiserat sig på marknadsföring till barn och ungdomar. Även om dessa inte kontrollerar hushållets portmonnä, är det ingen tvekan om att livsmedelsprodukter som barn efterfrågar kommer att inköpas av deras föräldrar.

Den andra strategin, att öka livsmedelskonsumtionen totalt, kan illustreras av amerikanska restauranger som framgångsrikt sålt under mottot "ät så mycket Du vill för 12 dollar och 95 cent". Det är intressant att en sådan strategi är speciellt framgångsrik i ett land som USA. Utbudet har ökat, och eftersom råvaran är en så obetydlig del av den totala produktens kostnad innebär det ingen särskild belastning att göra portionerna större. "Supersize your meal" är en fungerande affärskampanj i USA. Den som betalar bara lite mera får väldigt mycket mer kalorier på sin tallrik.

\section{Är mera bättre?}

En av mina kollegor försökte i en hamburgarrestaurang inhandla en vanlig hamburgare och en liten påse pommes frites, men fick veta att om han tog en mycket större hamburgare samt en stor pommes frites-påse samt läsk skulle hela måltiden bli 5 kronor billigare. Det var en specialerbjudande som ingen uppenbarligen kunde stå emot. Samtidigt har den amerikanske restaurangtallriken ökat i diameter under de sista 20 åren från 9,5 till 12 inches, och det är självklart att man inte skaffar större tallrikar, om man inte har tänkt lägga mera mat på dem. Coca-Cola har enligt Financial Times nyligen i USA lanserat en jättestor flaska med mottot "share with a buddy". Den jättestora läskedrycksflaskan är från början marknadsförd med tanken att den skall stimulera till gemensam läskedryckskonsumtion och i reklamkampanjen avbildas tvillingar, lagkamrater och vänner som lyckligt kluckar i sig ur den stora buteljen. Men på sikt är naturligtvis strategin, att man köper den 
stora flaskan, även om man inte har någon kamrat att dela med.

\section{Läskedrycken - ett uppseglande hälsoproblem}

Framför allt läskedrycker har blivit ett av våra stora problem. Forskningen har nyligen visat, att flytande socker, framför allt $i$ form av läskedrycker, inte ger de mättnadssignaler som socker eller andra former av kolhydrater i fast form ger. Det innebär, att det är lätt att släcka törsten med stora mängder av dessa 10\%-iga sockerlösningar utan att mättnadssignaler sätter in. Många av våra feta unga män dricker lätt fyra liter läsk per dag, vilket motsvarar cirka 1600 kalorier.

Möjligheterna att marknadsföra sina produkter utformas med långsiktig och kreativ strategi. Ett populärt mål under de senaste åren i USA har varit att leverera läskedrycksmaskiner till skolor. Skolorna, i USA kanske mera än i många andra länder, har ständigt dålig ekonomi, och möjligheten att bli delaktig i vinsten genom att få royalty på läskedrycksförsäljningen är oemotståndlig. Framför allt som pengarna ironiskt nog ofta går till att köpa idrottskläder till skolans lag, förbättra kvaliteten på gymnastiksalen eller göra annat som eleverna har glädje av, men som uppenbarligen inte kan finansieras inom ramen för gängse skolbudget. Skolorna får själva vara med att bestämma hur mycket läskedrycksförpackningen skall kosta och får en andel av vinsten. En omfattande aktivitet är nu på väg i USA där man försöker få bort läskedrycksmaskinerna ifrån skolorna.

I Norge har man i den framsynta Vegt-Helseutredningen föreslagit att det skall vara förbjudet att sälja snacks och läskedrycker inom en radie om $\mathrm{t}$ ex 500 meter ifrån skolan. Det kan tyckas förnumstigt och patetiskt men innebär ändå en ytterst respektabel ambition att göra någonting åt överkonsumtionen av sötade drycker som inte tillför någonting som eleverna behöver för sin hälsa.

\section{Jordbruksekonomi}

Ett skäl till att livsmedel är så billiga är naturligtvis de subventioner som jordbrukspolitiken i respektive land innebär. I Amerika är till exempel spannmåls- och sojabönsproduktionen väl subventionerad, vilket innebär att det finns möjligheter för bönderna att producera stora mängder till ytterst låg kostnad. Dessvärre är det så att de bönder som producerar nyttigheter, dvs frukt och grönsaker tjänar mindre på sin verksamhet. Denna form av livsmedelsproduktion har inte givits några subsidier.

\section{Etik - ett nytt tema?}

Livsmedelsindustrin drivs alltså av en ambition att växa - som alla andra professionella företag på marknaden. Det är orimligt att begära, att företagsledarna inom denna sektor skulle bete sig annorlunda mot aktieägarna än de som driver bilindustri, läkemedelsindustri eller någon annan företagsverksamhet. Men möjligen kan man spåra en tendens till en förändring: Företagsetik har blivit ett alltmera uppmärksammat ämnesområde, och många stora korporationer har faktiskt skaffat sig etiska referensgrupper, också ibland kunder och allmänhet. Det är tänkbart, att en ny etik kan medföra att man åtminstone börjar ransonera marknadsföringen till barn och ungdomar. I Sverige har vi sedan länge varit förskonade ifrån aggressiv marknadsföringen via TV till barn och ungdomar.

Marion Nestle understryker, att den konsumtionsökande verksamhet som livsmedelsindustrin ägnar sig åt ingalunda är olaglig, utan helt i linje med gällande bestämmelser. Kartellbildning är enstaka exempel på olaglig verksamhet, men för övrigt använder livsmedelsindustrin, om än med juridisk hjälp, samma möjligheter att på lagligt vis expandera som alla andra företag. Livsmedelsindustrin är kraftigt förankrad i maktens boningar i Washington, och stora lobbygrupper företräder intressenterna som $\mathrm{t}$ ex producerar juicer, spannmål och kött.

Om nu de allra största företagen varit framgångsrika i sin marknadsföring borde de mindre aktörerna på marknaden kunna slå sig samman och till exempel verka för att gemensamt argumentera för värdet av frukt och grönsaker. Dessvärre är många av dem misstänksamma mot sina konkurrenter. Istället för att slå sig samman och driva gemensamma kampanjer har man tvärtom motarbetat sina konkurrenter, vilket missgynnat hela branschen. När persikoodlare i Kalifornien ville gå ut med en kampanj för att påvisa, att persikan var en nyttig frukt, lade äppelodlarna in sitt veto och lyckades på juridiska grunder stoppa processen, eftersom äppelodlarna fruktade, att en framgång för persikoproducenterna skulle vara till förfång för äppelförsäljningen. Utan möjligheter till en gemensam strategi tycks företagen som säljer produkter vi egentligen inte behöver mer än sporadiskt vara de stora vinnarna. 


\section{Skatt på läsk}

I 13 amerikanska delstater har man numera infört skatt på läskedrycker. Det rör sig om en enda cent och kan naturligtvis ses som en mycket blygsam belastning, men läskedrycksindustrin har ändå motsatt sig skatten och drivit juridiska processer. En cents påslag på läskedryckspriset påverkar knappast konsumtionen, men principen finns där, och har man en gång fått in foten i dörren är det enkelt att fortsätta att höja. Vår svenska moms började vid 3 procents nivå... och alla vet vi var den ligger idag! De stater som lyckats genomföra den lilla skatten har dragit in en miljard dollar per år, eftersom läskedryckskonsumtionen är så gigantisk, men man har sannolikt missat en viktig pedagogisk poäng. Istället för att öronmärka dessa pengar till hälsoinriktade insatser har man låtit medlen gå direkt in $\mathrm{i}$ delstatens allmänna kassakista.
Sverige - bara lätt fasförskjutet efter USA

Även i Sverige blir vi fetare och fetare, och vi befinner oss egentligen på samma uppåtlutande plan som amerikanerna, även om vi är fasförskjutna mellan 10 och 15 år. Det är därför hög tid att diskutera vad vi skall göra nu. Att fetmaepidemin har nått Sverige står utom tvivel: Andelen feta svenskar har ökat med $50 \%$ de sista 20 åren, och andelen feta tonåringar med 24\% sedan 1980 . Det är alltså hög tid att börja handla, och alla fantasifulla och kreativa förslag bör tillvaratas. Att motverka en utveckling som i USA, kommer att kräva betydande insatser, försök till samsyn och väsentligt mera initiativ ifrån våra hälsobevarande myndigheter.

Stephan Rössner

E-mail: stephan.rossner@medhs.ki.se

\section{Kost och fysisk aktivitet läsåret 03/04}

Enheten för preventiv näringslära vid Karolinska Institutet ger fristående kurser om Kost och Fysisk aktivitet (Folkhälsonutrition). Kurserna ingår även i programmet European Master's in Public Health Nutrition, samt breddmagisterprogrammet Tillämpad Folkhälsonutrition.

Ht 2003

- Public Health Nutrition (5p)

- Principles of Health Promotion (7p)

- Beteendeförändring på området kost och fysisk aktivitet (10p, kvartsfart)

Juni 2003

- EU Basics in Public Health Nutrition, Aten (Grekland)
Vt 2004

- Principles of Physical Activity (3p)

- Folkhälsonutrition (10p)

- Assessment of Nutition and Physical Activity(7p)

Kontakta Jenny Rossen, 086083343 (jennny.rossen@prevnut.ki.se), se även www.prevnut.ki.se
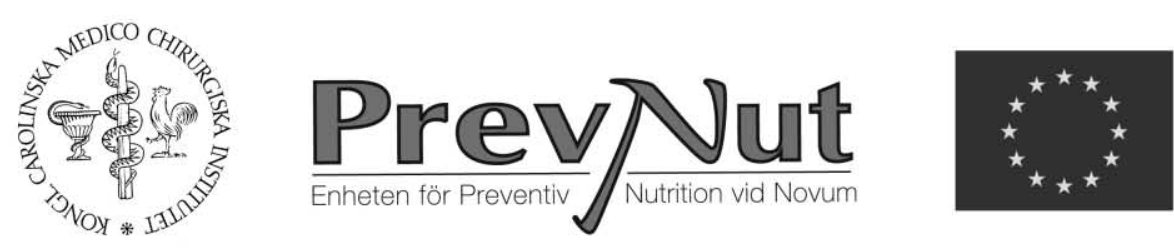